INDEPENDENT JOURNAL OF MANAGEMENT \& PRODUCTION (IJM\&P)

http://www.ijmp.jor.br

V. 10, n. 6, November-December 2019

ISSN: 2236-269X

DOI: 10.14807/ijmp.v10i6.945

\title{
SERVICE QUALITY MANAGEMENT -PRELIMINARY RESULTS OF SURVEY FOR CUSTOMERS
}

\author{
Manuela Krystyna Ingaldi \\ Czestochowa University of Technology, Faculty of Management, \\ Department of Production Engineering and Safety, Poland \\ E-mail:manuela@gazeta.pl
}

Submission: $12 / 28 / 2018$

Revision: $2 / 8 / 2019$

Accept: 2/27/2019

\section{ABSTRACT}

Quality is an important part of management in every enterprise. It is quality on which depends whether customers will buy products from a given enterprise, and, thus, the competitiveness of this enterprise on market. A special case is the quality of services and its assessment. There are many methods that can be used in such situations, which are widely described in the literature. It should be emphasized that in case of service quality, direct customer feedback about a given service is most often used, that is, the customers actively participate in this process. However, customers should be asked what method is the most friendly and least boring for them. The purpose of the paper is to present a survey on the use of methods of service quality assessment. In the paper preliminary results of the survey from point of view of customers are presented. The customers were asked to answer whether they were involved in such research, what their attitude to such research was, what research methods they encountered, and what problems occurred during such research.

Keywords: quality management, service quality, customer opinion 
INDEPENDENT JOURNAL OF MANAGEMENT \& PRODUCTION (IJM\&P)

http://Www.ijmp.jor.br

v. 10, n. 6, November-December 2019

ISSN: 2236-269X

DOI: 10.14807/ijmp.v10i6.945

\section{INTRODUCTION}

Among the important factors that need to be properly managed in every enterprise, the quality of products should be distinguished. It is the quality that determines the popularity of products on the market and the competitiveness of the enterprise, and thus its profit obtained from the sale of products.

As in any kind of process, also in the process of quality management, appropriate data is needed. This data concerns, inter alia, the quality level of the research product. In order to obtain such data, one should choose the appropriate quality assessment method, which will be the most adequate for the given enterprise and the products it offers (FROST; KUMAR, 2000; MATZLER, et al., 2004; PARASURMAN, et al., 1985; REICHHELD, 2003; NILSSON-WITELL; FUNDIN, 2005).

However, it should be remembered that the service quality is more difficult to assess than the product quality. Services are not tangible, their features cannot be measured, and the assessment is not free from subjectivity. In the case of services In the case of services, customers' expectations and their assessment of the provided services should be taken in to consideration ( $\mathrm{CHO}$, et al., 2016; CIAVOLINO; CALCAGNI, 2015; GUGLIELMETTI, 2001; MBISE; TUNINGA, 2016).

The service quality management is particularly important due to the very high competitiveness of the services in the market. It should be remembered that services are present at every step of our lives. People use some services are used on a daily basis, others from time to time without even realizing it (KLIMECKA-TATAR, et al., 2018; STOMA, 2012; ANAND; SELVARAJ, 2013; BITNER, et al., 1990).

Therefore, it can be said that selection of the appropriate methods for service quality assessment is the most important step in the analysis of quality. The success of using a given method can depend on this choice. Especially that the analysis of the service quality is carried out in a completely different way than in the case of material products.

There are many methods that can be used in such situations, and which are widely described in the literature. It should be emphasized that in case of service quality, direct customer feedback about a given service is most often used, that is, the customers actively participate in this process. Therefore, the choice of the method will 
INDEPENDENT JOURNAL OF MANAGEMENT \& PRODUCTION (IJM\&P)

http://Www.ijmp.jor.br

v. 10, n. 6, November-December 2019

ISSN: 2236-269X

DOI: 10.14807/ijmp.v10i6.945

determine what information will be obtained, but also whether customers will participate in the survey in a reliable and honest way. The longer the survey is, the less likely it is that the customer will be willing to participate (WONG, et al., 2011; ULEWICZ, 2014; RIVIÈRE, et al., 2006).

The most popular methods of service quality assessment, according to literature, are Servqual, CIT, Mystery Shopper and different types of indexes. While those methods, which are often omitted, are for example Servperf, IPA, Kano, penalty/rewards, problem detecting. Many of them are used by Polish service enterprises (ABADO, et al., 2007; LUPO, 2015; MAHMOUD; KHALIFA, 2015; CHEN; BARROWS, 2015; INGALDI, 2018a; INGALDI; ULEWICZ 2018).

Each of these methods has its pros and cons. Some of them are used by enterprises more often, some less often. By learning about their functioning, methodology and the possibilities of their use, it is easier to decide which method to choose. However, it should be remembered that not all of these methods at a given time and in a given enterprise can be used.

It should be emphasized that the research of literature indicated that there was a lack of research regarding customer feedback, who in most of these methods must participate and who express an opinion on a given service. And from their opinion, as mentioned earlier, the quantity and quality of information obtained on the quality of services depends. Hence the choice of the subject of research by the author.

The purpose of the paper is to present a survey on the use of methods of service quality assessment. In the paper preliminary results of the survey from the point of view of customers are presented. The customers were asked to answer whether they were involved in such research, what their attitude to such research was, what research methods they encountered, and what problems occurred during such research.

Preliminary research was carried out between September and December 2017. The research will be continued throughout 2018. The paper will allow to draw the first conclusions and possibly indicate the places in the questionnaire, which should be corrected before carrying out the main research or change the form of data collection.

At the same time, the research is conducted and analyzed from the point of view of the service enterprises (INGALDI, 2018b). The final results of the full research 
DOI: 10.14807/ijmp.v10i6.945

will help the service enterprises to choose right research method and can be used by various service enterprises.

\section{METHODOLOGY}

The research on the use of methods of the service quality assessment was carried out in the form of a questionnaire. The survey was completed by respondents from Southern Poland. The questionnaire was developed by the author of this paper and it is a part of a larger research project.

The questionnaire consisted of three sections: introductions to the questionnaire, proper questions and respondents characteristics. The introduction provides a brief description of the research and a formula with a request to fill in the questionnaire. In the main part, 19 questions were included. In the first questions customers indicated the frequency and type of services they use.

They were also supposed to say something about their approach to the service quality, where they get information about it and how much this quality is important to them. Next, they were asked to say whether they participated in the research about service quality. If yes, then they could go on to answer further questions. Further questions related to how many times they participated, in what kind of research, how to assess the ease of response in each method, what form of information collection suits them, what kind of questions they like to answer.

They were also supposed to say what problems they encounter most often during such researches, whether and why they interrupted or refused to participate in such a research. In the last part, obligatory for all, the respondents had to comment on the complaints about services, because they are a great source of information on quality.

The respondent data section includes 5 different characteristics of the participants.

In the survey different type of questions were used to additionally assess how people respond to them and if they have will to do it. Not all questions were obligatory due to the fact that some to respondents could not take part in service quality assessment.. For the same reason the responses include the option "I have no opinion" or "I do not know". 
INDEPENDENT JOURNAL OF MANAGEMENT \& PRODUCTION (IJM\&P)

http://Www.ijmp.jor.br

v. 10, n. 6, November-December 2019

ISSN: 2236-269X

DOI: 10.14807/ijmp.v10i6.945

A Google form was used to construct the survey. This enabled a quick correction in case of stylistic, grammatical errors, etc. It also helped in reaching a wider group of respondents and facilitated data collection. The link to the surveys was available through various websites, social networks.

The pilot research covered 112 respondents. Some of the surveys were omitted because they were incomplete or had errors, or filled in by people from outside the surveyed area, which is why 95 correctly completed surveys were finally taken. In the article, only the most important results are presented due to the editorial limitation. Their purpose was to check the customers' willingness to cooperate, how people completed the questionnaire and evaluated the survey itself.

Respondents were people living in southern Poland (this feature was checked on the basis of one of the respondents' characteristics - place of leaving). There were $64 \%$ of women and $33 \%$ of men among the respondents. Most of the respondents were people aged 21 to 30 years, followed by those aged 41 to 50 years. The respondents were mostly employees or students from schools and universities. Most of the respondents were people with a university degree or secondary education. These groups participate the most often in various on-line surveys. They are aware that their opinions are important and like expressing the opinions about various topics.

\section{RESULTS AND DISCUSSION}

To confirm that the respondents understand the concept of "service" and are able to distinguish it from the ordinary material product, at the beginning they were asked about how often they use various services, and then they had to list those services. Respondents most often responded (Figure 1) that every day (32\%), several times a week $(27 \%)$ or several times a day $(24 \%)$. The most frequently mentioned services were: transport (of various types), shopping, Internet, mobile telephony, petrol station, hairdresser, beauty salon, gastronomy, gas, water and energy supply services. It can be concluded that they understood the difference between a material product and a service.

Next, it was checked whether customers paid attention to the quality of provided services (Figure 2). 49\% of respondents answered that they always and $46 \%$ often. However, it cannot be said whether this is the actual situation or whether it is due to the subject of the survey in which they participated. 
DOI: 10.14807/ijmp.v10i6.945

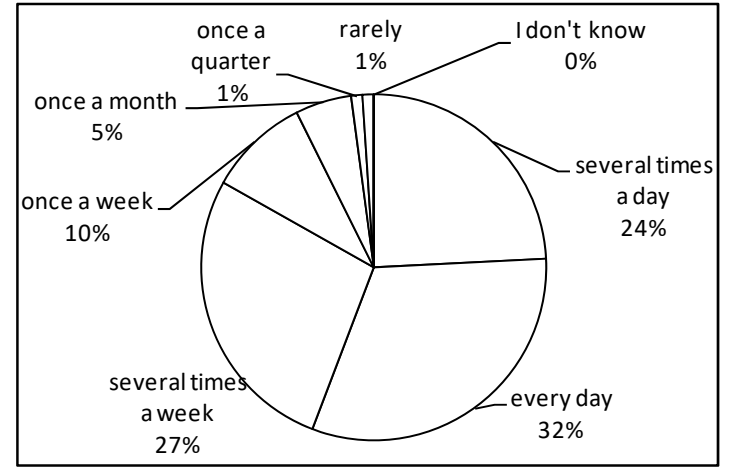

Figure 1: How often do you use different types of services? [\%] (own study)

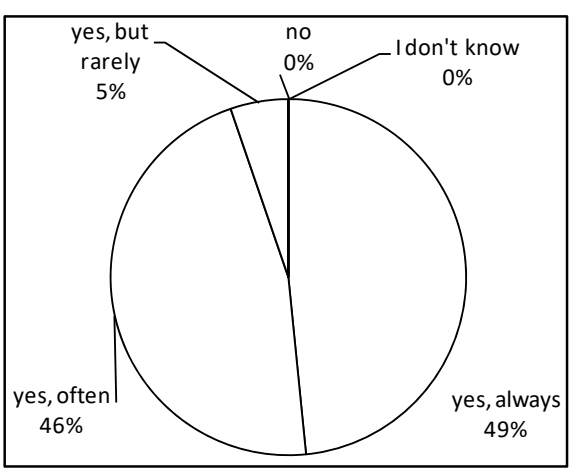

Figure 2: Do you pay attention to the quality of provided services? (own study)

Respondents were also asked where they had found information about service providers and the quality of services they offer (Figure 3). Customers could choose more than one answers. Most often they pointed to the friends' advice, their own experience as well as the websites and online forums. It turned out that customers do not really believe television or advertisements, despite the large amount of information provided in this form.

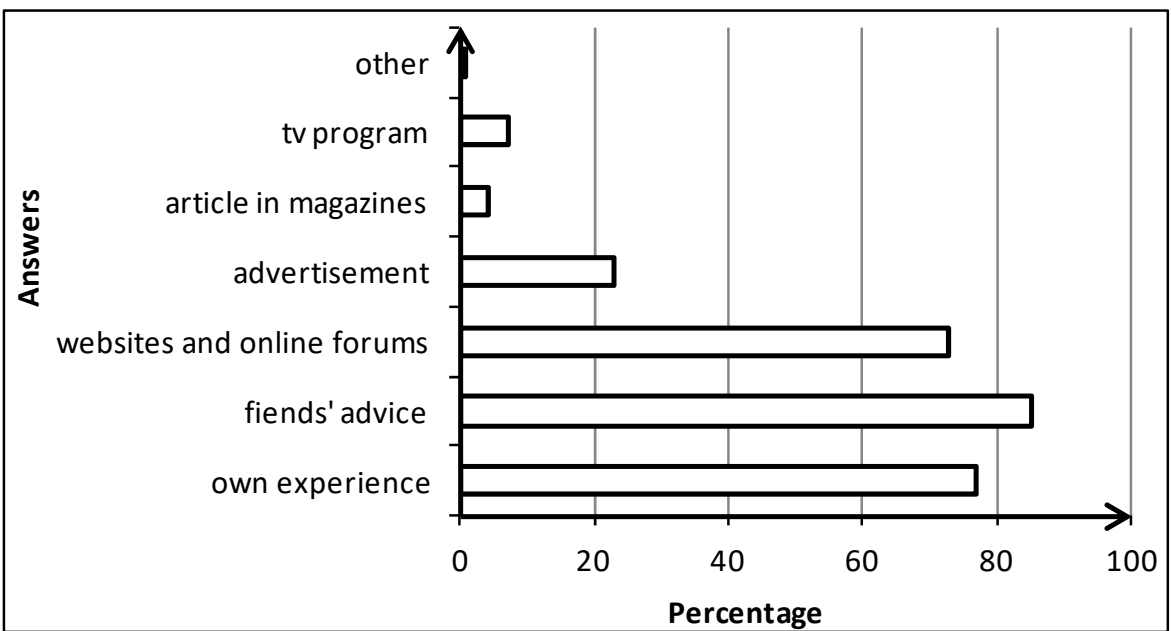

Figure 3: Where do you find information about service providers and the quality of services they offer? [\%] (own study)

Respondents were also asked to describe the meaning of the service quality for them (Table 1). It turned out that quality the most common means precision of execution, price adequate to the service and meeting customer requirements. The precision of execution and the meeting customer requirements may be related to the fact that many services are personalized. The customer can choose the individual features of the service that he wants to use, which is why he draws attention to this. The price adequate to the service is unfortunately associated with the salary potential of Polish people who often think about price when purchasing. 
INDEPENDENT JOURNAL OF MANAGEMENT \& PRODUCTION (IJM\&P)

http://Www.ijmp.jor.br

v. 10, n. 6, November-December 2019

ISSN: 2236-269X

DOI: 10.14807/ijmp.v10i6.945

Table 1: What does quality mean for you in the case of services? [\%] (own study)

\begin{tabular}{|l|c|}
\hline What does quality mean for you in the case of services? & Percentage fraction \\
\hline meeting customer requirements & 66.3 \\
\hline a large range of services & 21.1 \\
\hline a large selection of service features & 22.1 \\
\hline the amount of information available about the service & 33.7 \\
\hline possibility to change the service at various stages of its provision & 18.9 \\
\hline speed of execution & 46.3 \\
\hline precision of execution & 71.6 \\
\hline friendly service providers & 55.8 \\
\hline experienced service providers & 42.1 \\
\hline helpful service provider & 45.3 \\
\hline place of providing the service at the appropriate level & 20.0 \\
\hline satisfaction with the provided services & 42.1 \\
\hline price adequate to the service & 68.4 \\
\hline other & 0.0 \\
\hline
\end{tabular}

Subsequent questions concerned directly participation in research on service quality assessment. Respondents were asked whether they had participated in a research in which you assessed the quality of services (Figure 4) and if yes, how many times (Figure 5). 60\% of respondents declared participation in such a research, between which $40 \%$ of them several times, $41 \%$ do not remember how many times. It should be remembered that the description of the survey provided the purpose of the survey, the respondents knew what the questionnaire would be about, which may explain the result.

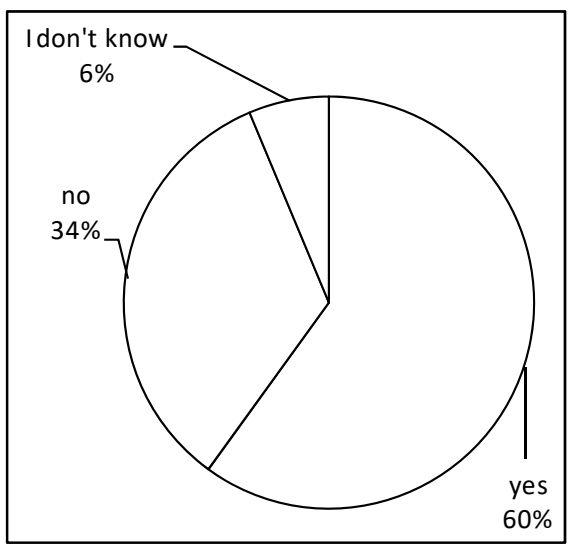

Figure 4: Have you participated in a research in which you assessed the quality of services? [\%] (own study)

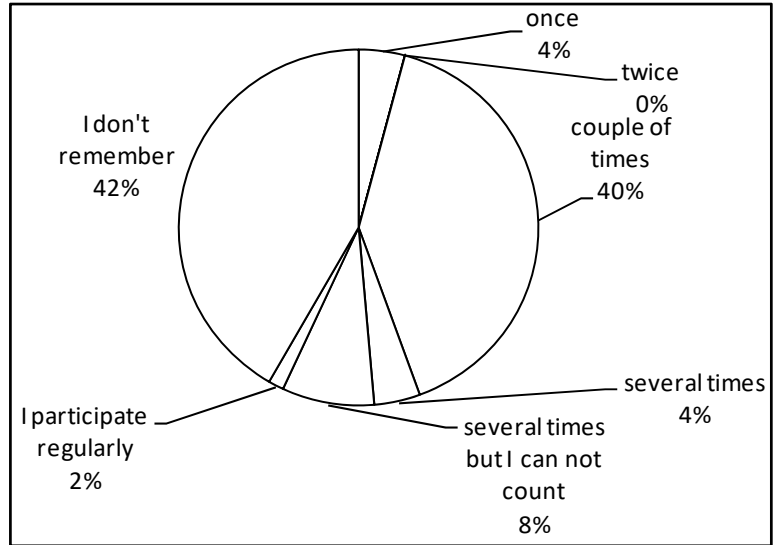

Figure 5: If you participated in a research in which you assessed the quality of services, how many times? [\%] (own study)

Then the respondents indicated what form of service quality assessment they had met (Tab.2). It should be emphasized that the names of specific research methods could not be given in the survey. The survey is expected to arrive to the widest possible 
INDEPENDENT JOURNAL OF MANAGEMENT \& PRODUCTION (IJM\&P)

http://www.ijmp.jor.br

V. 10, n. 6, November-December 2019

ISSN: 2236-269X

DOI: 10.14807/ijmp.v10i6.945

range of clients, regardless of their knowledge or education. An ordinary customer can describe the research in which he participated, but cannot name it.

Respondents the most often indicated short survey (a few questions about the service), questions about possible re-purchase and questions about a possible service recommendation to friends. It is surprising that there is a different percentage in the case of describing positive and negative events related to the service, although the difference is not so great, and it is nothing else than the CIT method. Respondents rarely encountered methods assessing expectations and features of the actual service (e.g. Servqual, IPA, Kano). Perhaps Polish enterprises rarely use such methods.

Table 2: What form of service quality assessment have you met? [\%] (own study)

\begin{tabular}{|l|c|}
\hline What form of service quality assessment have you met? & Percentage fraction \\
\hline Questions about possible re-purchase & 56.8 \\
\hline Questions about a possible service recommendation to friends & 44.2 \\
\hline Short survey (a few questions about the service) & 58.9 \\
\hline Long survey assessing the features of the service & 10.5 \\
\hline $\begin{array}{l}\text { Long survey assessing your expectations and features of the actual } \\
\text { service }\end{array}$ & 8.4 \\
\hline Describing positive events related to the service & 12.3 \\
\hline Describing negative events related to the service & 18.6 \\
\hline Assessment of customer satisfaction & 3.2 \\
\hline I don't remember & 1.1 \\
\hline
\end{tabular}

There are many forms of data collection that can be used in this case. Between the most customer-friendly (Tab. 3) respondents indicated online survey.

Table 3: What form of data collection according to you is the most customer-friendly? [\%] (own study)

\begin{tabular}{|l|c|}
\hline $\begin{array}{l}\text { What form of data collection according to you is the most customer- } \\
\text { friendly? }\end{array}$ & $\begin{array}{c}\text { Percentage } \\
\text { fraction }\end{array}$ \\
\hline Direct conversation straight after the service provision (direct interview) & 37.9 \\
\hline $\begin{array}{l}\text { Telephone call after service provision (direct interview after the customer's } \\
\text { visit) }\end{array}$ & 13.7 \\
\hline Paper survey handed to the customer & 27.4 \\
\hline Paper survey placed in the lobby & 16.8 \\
\hline Online survey & 62.1 \\
\hline Business card with a link to an online survey & 17.9 \\
\hline E-mail with questions or survey & 30.5 \\
\hline I don't know & 0.0 \\
\hline Other & 0.0 \\
\hline
\end{tabular}

If it comes to completing the online survey, customers feel relaxed, more willing to answer, do not have a person who takes such a questionnaire from them, so they 
do not have to be afraid that someone will connect them directly with the answers. Anyway, there is a phenomenon on the Internet. It is easier for people to express themselves, express their opinion, become experts on everything, often offending others, feeling unpunished.

Among the types of questions that are used in various surveys (Figure 6), a the most often respondents indicated closed questions with one or several answers and assessment scales. They may not want to express themselves in such research, they do not like expressing themselves in writing. Such questions are answered more quickly.

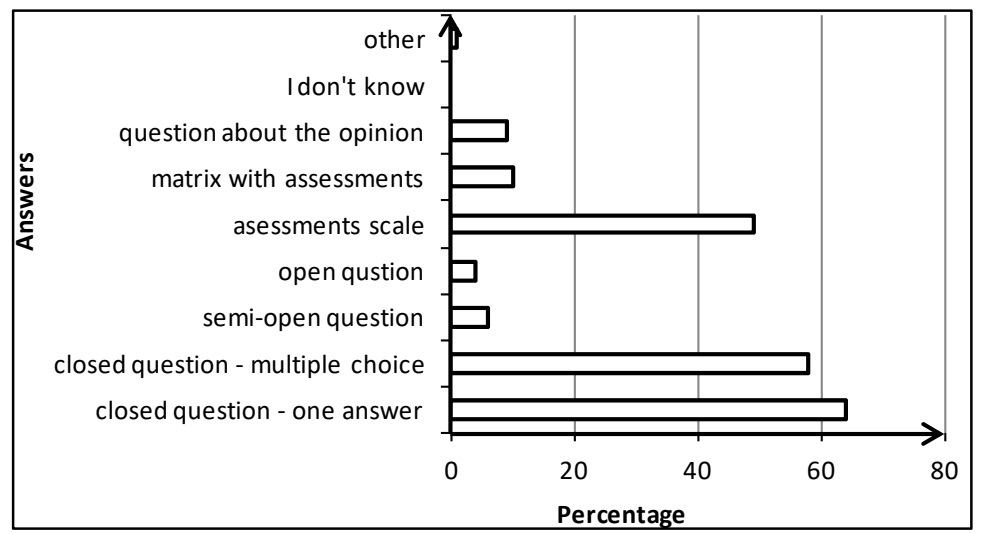

Figure 6: Which questions do you like the most? [\%] (own study)

Unfortunately, during such surveys, customers often encounter many problems (Figure 7). These are mainly: poorly worded questions (perhaps just written in a language too difficult to understand), too many questions and no matching answer. The problem with too many questions may explain the fact that such surveys are not popular among respondents. This may also affect the interruption or refusal to participate in the research.

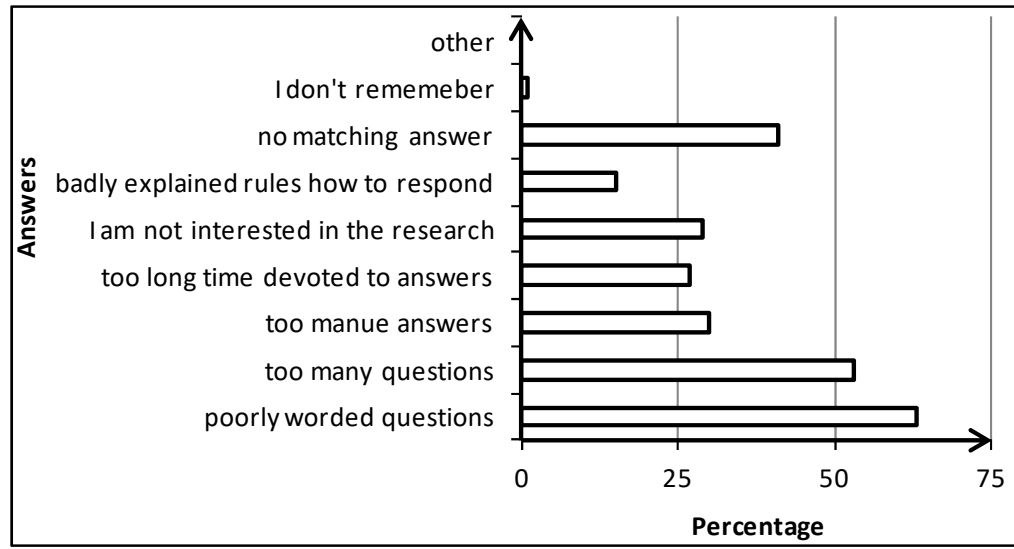

Figure 7: What problems do you encounter during the response? [\%] (own study) 
INDEPENDENT JOURNAL OF MANAGEMENT \& PRODUCTION (IJM\&P)

http://www.ijmp.jor.br

v. 10, n. 6, November-December 2019

ISSN: 2236-269X

DOI: 10.14807/ijmp.v10i6.945

As far as a survey interruption is concerned (Fig. 8), $70 \%$ of respondents confirmed that they had done it. There are many reasons for such situations (Tab. 4). Among the most frequently reported, it should be indicated that it took more time than they had expected, the interviewer was too insistent, the way to respond questions seemed too complicated. The issue of pressing interviewers may explain the indication of an online survey as the one that is the most friendly to the respondents.

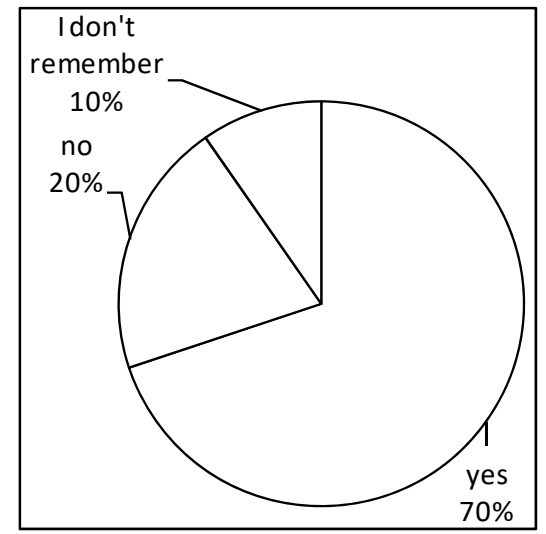

Figure 8: Have you even interrupted the survey? [\%] (own study)

Table 4: If you have ever interrupted the survey, why? [\%] (own study)

\begin{tabular}{|l|c|}
\hline If you have ever interrupted the survey, why? & Percentage fraction \\
\hline It took more time than I expected & 67.4 \\
\hline Too-extensive questions & 25.3 \\
\hline I was bored & 30.5 \\
\hline The way to respond questions seemed too complicated & 45.3 \\
\hline Interviewer asked at the wrong moment & 23.7 \\
\hline One question made you upset & 7.4 \\
\hline The interviewer was too insistent & 43.2 \\
\hline I don't remember & 6.3 \\
\hline Nothing & 0.0 \\
\hline Other & 1.1 \\
\hline
\end{tabular}

It was also asked whether respondents have ever refused to take part in such a research (Figure 9). $87 \%$ of respondents confirmed. They usually excused themselves with the lack of time (Fig. 10). 


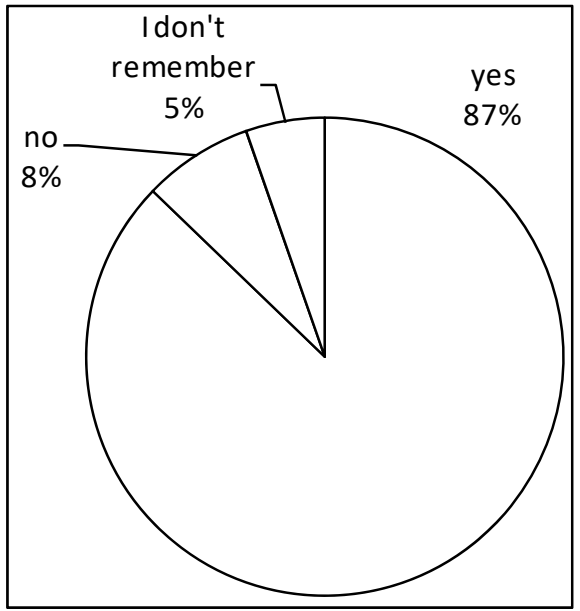

Figure 9: Have you ever refused to take part in such a research? [\%] (own study)

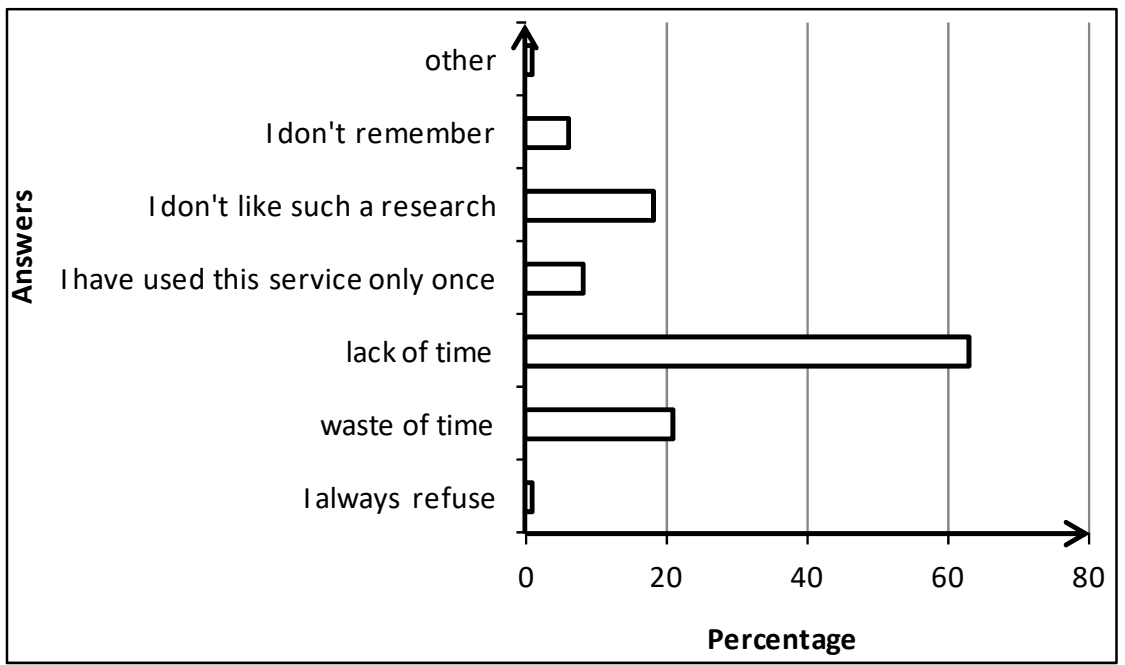

Figure 10: If you have ever refused to take part in such a research, why? [\%] (own study)

\section{SUMMARY}

In the paper the preliminary research on the use of service quality methods from the point of view of customers was presented. The research covered 95 people from southern Poland and it had a form of Internet survey. Some surveys were omitted because they were incomplete or had errors.

Despite the fact that it was only preliminary research, it was quite popular among customers, even more than in the case of the same research conducted from the point of view of service enterprises which was carried out in the same time and presented in paper (INGALDI, 2018b).

Respondent, who took part in the preliminary research, claimed that they paid attention to the quality of services, and they obtained information about the service 
from own experience, friends' advices and Internet. According to them the service should be precisely provided, all their requirements met and price adequate to the service.

Most of respondents participated in research on the service quality and its assessment. Most often, they indicated short surveys or questions about possible repurchase. They preferred online surveys, that keep them anonymous, and their favorite question were closed questions with one or more answers and assessment scales. Respondents during such a research also encountered many problems such as poorly worded questions, too many questions or no matching answers, what is more, they often refused to take part in such a research. These are the first recommendations for the enterprises that would like to assess the quality of services they provide.

The analysis of the results of the preliminary research allowed to indicate several problems that can occur during the research on the service quality and which should be avoided. Respondents were reluctant to answer questions that required writing a response. Only in the case of open questions the answers were given, though not always. In the case of semi-open questions, the answer "other" was often marked, but in spite of the field no one gave the additional answer. A similar situation was observed by the author in the case of a preliminary research carried out from the point of view of enterprises presented in paper (INGALDI, 2018b). Despite the fact that such questions give lots of information to the enterprises, also their representatives often omitted writing responses.

It should also be remembered that the use of customers when analyzing the service quality, their opinions is not easy, because we have no influence on how they answer questions, whether they do it conscientiously. There is even one thing more important, what the management of the enterprise will do with the information obtained in this way.

In the paper only preliminary results are presented while the research is continued in 2018 and 2019. At the same time, research will be conducted both from the point of view of the customer and the service enterprises. In the future the results from both points of view will be compared and conclusions will be drawn. 
INDEPENDENT JOURNAL OF MANAGEMENT \& PRODUCTION (IJM\&P)

http://Www.ijmp.jor.br

V. 10, n. 6, November-December 2019

ISSN: 2236-269X

DOI: 10.14807/ijmp.v10i6.945

Thanks to the research, it will be possible to indicate methods of the service quality assessment most often used by Polish service enterprises, to determine the manner of conducting such an assessment according to the opinions of customers and service providers, to determine the most frequent problems faced by customers and service providers. These results can be used by enterprises from various parts of the world to design a course of research on the services they provide.

\section{REFERENCES}

ABALO, J.; VARELA, J.; MANZANO, V. (2007) Importance values for ImportancePerformance Analysis: A formula for spreading out values derived from preference rankings. Journal of Business Research, v. 60, p. 115-121.

ANAND, S. V.; SELVARAJ, M. (2013) Evaluation of Service Quality and its Impact on Customer Satisfaction in Indian Banking Sector - A Comparative study using Servperf. Life Science Journal - Acta Zhengzhou University Overseas Edition, v. 10 , n. 1, p. 3267-3274.

BITNER, M. J.; BOOMS, B. H.; TETREAULT, M. S. (1990) The Service Ecounter: Dignosing Favourable and Unfavourable Incidents. Journal of Marketing, v. 54, n. 1, p. 71-84.

CHEN, R. J. C.; BARROWS, C. W. (2015) Developing a Mystery Shopping Measure to Operate a Sustainable Restaurant Business: The Power of Integrating with Corporate Executive Members' Feedback. Sustainability, v. 7, n. 9, p. 12279-1229.

CHO, I. J.; KIM, Y. J.; KWAK, C. (2016) Application of SERVQUAL and fuzzy quality function deployment to service improvement in service centres of electronics companies. Total Quality Management \& Business Excellence, v. 27, n. 3-4, p. 368-381.

CIAVOLINO, E.; CALCAGNI, A. (2015) Generalized cross entropy method for analysing the SERVQUAL model. Journal Of Applied Statistics, v. 42, n.3, p. 520534.

FROST, F. A.; KUMAR, M. (2000) INTSERVQUAL: an internal adaptation of the GAP model in a large service organization. Journal of Services Marketing, v. 14, n. 5, p. 358-377.

GUGLIELMETTI, R. (2001) L'attenzione al cliente: approccio teorico. In: CAPPELLI, L.; RENZI, M.F. (ed.), Management della qualità, Padova: CEDAM.

INGALDI, M. (2018a) Overview of the main methods of service quality analysis.

Production Engineering Archives, n. 18, p. 54-59.

INGALDI, M. (2018b) Methods of Service Quality Assessment - Preliminary Results of Survey for Enterprises. In: 10th International Scientific Conference Business and Management 2018, Vilnius, LithuaniaBusiness and Management 2018, Vilnius, 418-426.

INGALDI, M.; ULEWICZ, R. (2018) Evaluation of Quality of the e-Commerce Service. International Journal of Ambient Computing and Intelligence, v. 9, n. 2, p. 55-66. 
KLIMECKA-TATAR, D.; KOWALIK, K.; BROZOVA, S. (2018) Service Quality Model Based on the 4Q's Model and the System Approach to Service Quality Management. In: OKREEGLICKA, M.; KOROMBEL. A.; LEMAŃSKA-MAJDZIK, A. (ed.), Proceedings of the 2nd International Conference Contemporary Issues in Theory and Practice of Management, Czestchowa: Wydawnictwo Wydzialu Zarzadzania Politechniki Czestochowskiej, p. 236-243.

LUPO, T. (2015) Fuzzy ServPerf model combined with ELECTRE III to comparatively evaluate service quality of international airports in Sicily. Journal Of Air Transport Management, n. 42, p. 249-259.

MAHMOUD, A. B.; KHALIFA, B. (2015) A confirmatory factor analysis for SERVPERF instrument based on a sample of students from Syrian universities. Education And Training, v. 57, n. 3, p. 343-359.

MATZLER, K.; BAILOM, F.; HINTERHUBER, H. H.; RENZL, B.; PICHLER, J. (2004) The asymmetric relationship between attribute-level performance and overall customer satisfaction: a reconsideration of the importance-performance analysis. Industrial Marketing Management, n. 33, p. 271-277.

MBISE, E. R.; TUNINGA, R. S. J. (2016) Measuring business schools' service quality in an emerging market using an extended SERVQUAL instrument. South African Journal Of Business Management, v. 47, n. 1, p. 61-74.

NILSSON-WITELL, L.; FUNDIN, A. (2005) Dynamics of service attributes: a test of Kano's theory of attractive quality. International Journal of Service Industry Management, v. 16, n. 2, p. 152-168.

PARASURMAN, A.; ZEITHAML, V. A.; BERRY, L. L. (1985) A conceptual model of service quality and its implications for the future research. Journal of Marketing, $v$. 4, n. 4, p. 41-50.

REICHHELD, F. F. (2003) One Number You Need to Grow. Harvard Business Review, v. 81, n. 12, p. 46-54.

RIVIĖRE, P.; MONROZIER, R.; ROGEAUX, M.; PAGÈS, J.; SAPORTA, G. (2006) Adaptive preference target: Contribution of Kano's model of satisfaction for an optimized preference analysis using a sequential consumer test. Food Quality and Preference, v. 17, n. 7, p. 572-581.

STOMA, M. (2012) Modele i metody pomiaru jakości usług. 1 ed. Lublin: Q\&R Polska Sp. z o.o.

ULEWICZ, R. (2014) Application of Servqual method for evaluation of quality of educational services at the university of higher education. Polish Journal of Management Studies, n. 9, p. 254-264.

WONG, M. S.; HIDEKI, N.; GEORGE, P. (2011) The Use of ImportancePerformance Analysis (IPA) in Evaluating Japan's E-government Services. Journal of Theoretical and Applied Electronic Commerce Research, v. 6, n. 2, p. 17-30. 